\title{
Hypoglycaemic Activity and Biochemical Effects of Vernonia amygdalina with Diabenese in Normal and Diabetic Rats
}

\author{
Jones, B.B ${ }^{1}$, Tabe, N. $\mathbf{N}^{1}$, Ushie, $\mathrm{O}^{\mathbf{2}^{*}}$ \\ ${ }^{1}$ Department of Chemical Science, Cross River University of Technology Calabar, Nigeria \\ ${ }^{2}$ Department of Chemical Science, Federal University Wukari Nigeria
}

*Corresponding Author: Ushie, $\boldsymbol{O}$ A, Department of Chemical Science, Federal University Wukari

Nigeria. Email: afiushie@yahoo.com

\begin{abstract}
This study examined the complications of diabetes mellitus resulting from increased free radical load compounded by toxicity of conventional drugs employed for treatment of the disordered. Herbs which are rich sources of vitamin $C$ and $E$ (antioxidants) may therefore alleviate these toxic side effects. The hypoglycaemic activity and biochemical effects of vernonia amygdalina, with diabenese in normal and diabetic rats were compared. Ethanollic extracts of $V$. amygdalinawere screened for their phytochemical constituents using standard methods. Biochemical effects were evaluated on alloxan induced diabetic rat (32) assigned into four study groups of eight rats each Group 1 (control) received diabinse (14.28mg/kg). V. amygdalina $(40 \mathrm{mg} / \mathrm{kg}$ ) in $30 \%$ ethanol vehicle respectively by oral gavage. At the end of 21 day administration period blood serum was obtained from sacrificed animals and biochemical indices of toxicity (lipid profile, aminotransferases activity, serum protein, urea and albumin).
\end{abstract}

\section{INTRODUCTION}

Diabetes mellitus is a chronic endocrinologic disorder characterized by high blood glucose levels arising from insufficient secretion of insulin by the pancreas or improper utilization by target cells. Diabetes is the most common endocrinologic disorder with widespread prevalence cutting across all populations groups. The insufficient secretion of insulin by pancreatic islet calls or detective insulin receptors.Leads to poor utilization of insulin by target cells culminating in raised fasting blood glucose levels $(>8 \mathrm{mmoi} / \mathrm{L})$ glycosylated haemoglobin $(\mathrm{Hb} \mathrm{A} / \mathrm{C})$ greater than $6-9 \%$. Glycosylated haemoglobin gives and indication of average blood glucose concentration over a $6-8$ week period and is a biochemical test used for monitoring progression of diabetes or response to treatment. While the capillary or a venous glucose valve gives the blood glucose levels. Besides the immediate perceptible metabolic disfunction accompanying hyperglycemia. There are long - term complication of diabetes mellitus involving disorders of the eyes, kidneys, nerves and blood vessels.

\section{MATERIALS AND METHODS}

The ethanolic extracts of cataranthus roseus and Vernonia amygdalina were subjected to phytochemical screening to establish their phytochemical compositions. Ninety rats (Males and Females) of wistar strain weighing 140-245g obtained from the animal house. Department of Biochemistry, University of Calabar. Diabetes was induced on a pool of seventy rats by intraperitioneal injection of $150 \mathrm{mg} / \mathrm{kg}$ body weight of alloxan monohydrate (sigma, st Louis, Mo. USA). Using distilled water as the vehicle. The research work was organised, into phases. Phase 1 and phase 11 . The first consisted of 24 diabetic and non-diabetic (normal) animals respectively assigned into 4 groups of six rats each. These were used for hypoglycaemic assessment only on the hand. The second phase consisted of purely diabetic animals (32 animals) also assigned into 4 groups of eight each and tread as in phase 1.

Treatment was administered twice a day by gastric intubation in a 12 hour cycle $7.00 \mathrm{am}$ and $7.00 \mathrm{pm}$ for 14days. Body weight of the animal monitored after every two days throughout the administration period using a beam balance. Twelve hours after last feeding and administration (overnight fast) the animals were anesthetized under chloroform vapour then dissected. Whole blood was collected from the heart by cardiac puncture and divided into two fractions. Serum triglyceride level was estimated 
with the use of Dialab laboratory kit. The method employs enzymatic hydrolysis of triglyceride in the sample with lipoprotein lipase (LPL).In Hayems and Turks fluids a 1:200 dilution of blood was made by taking 20 microlitres of blood in a glass tube $(75 \times 12 \mathrm{~mm})$. The tube sealed with rubber band was tilted through an eagle of 120 and rotated for 2 minutes. With a Pasteur pipette. the country chamber (New improved neubauer country chamber) was filled with the diluted blood sample, ensuring that no blood spilled into surrounding moat, The cells were allowed to settle by leaving the chamber undisturbed for 2 minutes, after which the cells were counted under low magnification $(4 \mathrm{~mm}$ dry objective and $\mathrm{x} 10$ eye piece).

\section{STATISTICAL}

Data obtained was expressed as meant standard deviation and analysed the Analysis of variance (ANONA) or student's t-test where applicable. Values $\mathrm{P}<0.05$ were regard as significant in comparison to appropriate controls.

\section{ReSUlts}

Table1. Phytochemical composition of Ethanolic extracts of Vernonia amygdalina

\begin{tabular}{|l|l|}
\hline Phytochemicals & Vernonia amygdalina \\
\hline Alkaloids & ++ \\
\hline Saponins & ++ \\
\hline Polyphanols & ++ \\
\hline Triterpenes & ++ \\
\hline Cardiac glycosides & ++ \\
\hline Flavoniods & ++ \\
\hline Tannins & - \\
\hline Anthraquinones & - \\
\hline Steroids phlobatarvins & - \\
\hline Hydroxymethyl & - \\
\hline
\end{tabular}

Phytochemical composition of Vernonia amygdalina shows that alkaloids. saponins, polyphanols. triterpenes. Cardiac glycosides and flavoniods were present in Vernonia amygdalina

\subsection{Effect of Treatment on Blood Glucose Concentration of Rats Show Comparative Effect of Ethanoic Extracts of Vernonia amygdalina and Diabinese Treatment on Serum Glucose of Diabetic Animals}

Effect of treatment on blood glucose concentration of rats show comparative effect of ethanoic extracts of Vernonia amygdalina and diabinese treatment on serum glucose of diabetic animals indicated $81.32 \pm 5.32$, and $76.60 \pm 5.55$ for diabinese and Venonia amygdalina respectively and diabetic rats. Treatment with these drugs reduced significantly $(\mathrm{P}<0.05)$ serum glucose levels of normal non-163.05 \pm 3.75 and $142.29 \pm 4.54$ respectively) for diabeinese, and Vernonia amygdalina relative to their respective controls (107.88 and $247 \pm 4.83$ for normal and diabetic rats).

Table2. Comparative effect on fasting blood glucose $(\mathrm{mg} / \mathrm{dl})$ following a 21day administration of diabinese and $V$. amygdalina extracts on normal and diabetic rats

\begin{tabular}{|l|l|l|}
\hline Treatment groups rat & Normal-Diabetic rats & Diabetic rat \\
\hline Control $(30 \%$ ethanol & $107.88 \pm 7.38$ & $247.25 \pm 4.83$ \\
\hline Diabinese treated $(14.29 \mathrm{mg} / \mathrm{kg})$ & $* 81.31 \pm 5.32$ & $* 163.05 \pm 3.75$ \\
\hline$\underline{\mathrm{V}}$ amygdaline treated $(400 \mathrm{mg} / \mathrm{kg})$ & $* 76.60 \pm 5.55$ & $* 142.29 \pm 4.54$ \\
\hline
\end{tabular}

Values of expressed as mean $\pm S D,=6$

*= Statistically significant $(P<0.05)$ compared with controls values without asterisks are not significant.

\subsection{Effect of Treatment on Serum Lipid Fraction of Diabetic Rats}

The comparative effects ethanolic extracts of vernonia amygdalina cataranthus roseus and diabetes on serum lipid fractions including Total cholesterol. Triglycerides (TG) and High density lipoprotein have been shown in table 3. Treatments with diabinse produce decreases in Total Cholesterol and Triglycerides but an increase in High density lipoprotein of these changes only that of Triglycerides was significant $(88.16 \pm 25.41)$ compared to the control $(142.19 \pm 40.13)$. Treatment with 
Vamgydalina extract caused significant decreases $(\mathrm{P}<0.05)$ in total cholesterol $(50.44 \pm 12.17)$ and triglycerides $(62.96 \pm 18.92)$ decrease $(\mathrm{P}>0.05)$ in HDL level $(39.99 \pm 18.92)$ when compared to their respective controls $(69.98 \pm 9.50,142.19 \pm 40.13$ and 43. 4.00) Treatment with diabinse however, caused significant decrease $(\mathrm{P}<0.05)$ in High density lipoprotein level $(33.99 \pm 8.25)$ and a decreases in total cholesterol $(63.62 \pm 16.11)$ and triglycerides $(86.16 \pm 18.92)$ compared to their respective controls. The decreased was only significant in total cholesterol $(\mathrm{P}<0.05)$ and not total cholesterol.

Table3. Comparative effect of diabinese, ethanolic extracts of Vamygdalina on serum lipids of diabetic rats treated for 21 days.

\begin{tabular}{|l|l|l|l|}
\hline Treatment Groups & Total Cholesterol $(\mathrm{mg} / \mathrm{dl})$ & Triglycerides $(\mathrm{mg} / \mathrm{dl})$ & High density Lipoprotein $(\mathrm{mg} / \mathrm{dl})$ \\
\hline Diabetic Control & $69.98 \pm 9.50$ & $142.19 \pm 40.13$ & $43.10 \pm 4.00$ \\
\hline Diabetic Diabinse treated & $63.62 \pm 16.11$ & $* 88.16 \pm 18.92$ & $39.99 \pm 8.25$ \\
\hline $\begin{array}{l}\text { Diabetic_V_Amygdalina } \\
\text { treated }\end{array}$ & & $* 62.96 \pm 12.17$ & $39.99 \pm 8.25$ \\
\hline
\end{tabular}

Values represented mean $\pm S D n=8$

$*=$ Statistically significant $(P<0.05)$ compared with the control

**= Statistically significant $(P<0.01)$ compared with the control without estensilis are not significant.

Table4. Effect of a 21 day treatment with diabinese ethanolic extract of $\underline{V}$. amygdalina and $C$. reseus on serum levels of total protein, albumin and urea of diabetic rats

\begin{tabular}{|l|l|l|l|}
\hline Treatment Group & Total Protein $(\mathrm{g} / \mathrm{dl})$ & Albumin $(\mathrm{g} / \mathrm{dl})$ & Urea $(\mathrm{mg} / \mathrm{dl})$ \\
\hline Diabetic control & $7.16 \pm 0.52$ & $3.43 \pm 0.14$ & $7.30 \pm 6.67$ \\
\hline Diabetic diabinese treated & $* 8.41 \pm 0.98$ & $3.39 \pm 0.34$ & $* * 12.63 \pm 0.29$ \\
\hline Diabnetic vernonia amygdalina treated & $* 8.22 \pm 0.58$ & $* 2.99 \pm 0.23$ & $* * 28.30 \pm 2.39$ \\
\hline
\end{tabular}

Values represent mean $\pm S D n=8$

$*=$ Statistically significant $(P<0.05)$ compared with control

$* *=$ Statistically significant $(P<0.01)$ compared with control

Value without asterisks.

\subsection{Treatment Effect on Aminotransferaces Activity of Diabetic Rats}

Aminotransferace activities were determined and the resuits serum AST activity decreased in treatment $(101.00 \pm 10.42$ and $102.67 \pm 10.62$ for diabetic diabinese treated and diabetic vernonia amygdalina treated respectively). Compared to the control $(110.13 \pm 14.26)$. The decrease were however, non significant $(\mathrm{P}>0.05)$ Serum ALT activity in serum also decreased upon treatment $(14.62 \pm 2.90,15.50 \pm 3.60$ and $13.13 \pm 1.31$, diabetic diabinese treated, diabetic vernonia amygdalina treated and CrT respectively). The decrease in ATL was only significant $(\mathrm{P}<0.05)$ in the group treated with C. roseus (DCRT).

\section{DISCUSSION}

Phytochemical composition of any plant material defines to a large extent the relevance of such a plant in its ecological zone, both to its population and the community phytochemicals of diverse plant have exhibited toxicity to the animal population as well as profound ethnomedicinal and pharmacological properties. The pharmacologic and medical value of any plant material therefore, is a function of its phytochemical composition.

Vernonia amygdalina traditional antidaibetic plant in some African population were screened in this research for their phytochemical compositions. resuits demonstrated medium presence of saponins and flavonoids in $V$ amygdalina. The presence of these substances may be responsible for their anti hyperglycaremia action. Win/eman (1989) had earlier in his report indicated that plants endowed with flavoids. glycosides and phytosterols are likely to posses both hypoglycaemia and antihyperglycemic action.

Serum lipid fraction information available from pathophysiology reveals that it is associated with lipoprotein abnormalities due to defect in insulin, which is an antihyperglyceridemic and lipogenic hormone. As a consequence diabetes have increased risk for development of premature atherosdenosis 
due to the increased HDL levels (Bierman. 1992).In this study total cholesterol and triglycerides raised in diabetes controls were reduced significantly following treatment with the herbs and diabinese. This result for Vernonia amygdaline extract is consistent with the reports of Akah et al 92002). Nimenibo-Uadia. (2003) and Uhegbu and Ogbuehi (2004). The authors had earlier reported the anihypertriglyceridemic and antihypercholesterol action of Vernonia amygdaline extracts.

Considering the efficacy of the various treatments, Vernonia amygdalina appeared to be more efficacious in lowering blood cholesterol and triglyceride levels. The rich saponin content of Vernoniaamygdalina responsible for its copious foaming may have been responsible. The saponins are taught to bind cholesterol to bile acids. Consequently lowering cholesterol in plasmic (NimeriboUadia, 2003).

However, the effects of $\mathrm{C}$. roseus and to a lesser extent diabinese are more beneficial with respect to HDL. Vernonia amygdalina rather caused a decreased though not significant. Some of the indices assayed after 21days administration period. Indicates that the herbs could protect the diabetic animals better than the standard drug. The herbs also proved more efficacious in their hypoglycemic action.

Blood glucose lowering effect: Blood glucose monitoring remains the most relevant index of diabetic status and progress monitoring following a treatment plan hyperglycermia has been described as the common denominator (Ireland et al., 1980) and the common manifestation (magfield, 1998) of diabetes mellitus. Blood glucose way assayed in this work following treatment of both diabetic and non-diabetic animals. The observation of hypoglycaemic activity in both normal and diabetic rats for Vamygdalina agree with previous report of Iwu (1983). These diabetic rats is not surprising as the flavonids glucosives andphytosterols are implicated respectively in hypoglycaemic and antihypoglycemic action. This might be due to relative abundance of the respective glucose lowering phytochemicals, for instance, tannias have been implicated in glucose lowering action via a similar effect upon which they exhibit toxicity (Nimenibo-Uadia 2003). For V amygdalina reports of its hypolycemic and antihypolycemic activity are found in literature. The resuits here only lends credence to such reports. Diabinse though both hyperglycermic and antihyperglycemic. The herbs appear to be more efficacious in their activity. This difference may be due to the fact that there are more than just a single phytochemical with glucose lowering action in the herbs. These may have acted synergistically to produce a more pronounced effect as compared to diabinse which is just a single purified agentchlorpropama with a tissue directed action. The diverse phytochemicals may also affect various tissues and organs as well as enzymes insulin related and non- insulin related to achieve an effectual control.

\section{REFERENCES}

[1] Bailey, C. J. \& Day, C. (1989). Traditional plant medicines as treatments for diabetes. Diabetes Care 12,553-564

[2] Canadian Diabetes Association (2003). Clinical practice guidelines for prevention and management of diabetes in Canada. Ontario: Canadian Diabetes Association.

[3] Clavell. M. C. (2002). Managing diabetes in Mayo, I. (ed). Mayo Foundation For medical education and research ( $2^{\text {nd }}$ edition) (pp.5-20). New York: KanSington press.

[4] Greoff, O. R. W. (2000). The Management of diabetes mellitus. Genee Skunde: The Medicine Journal. October 2000. Retrieved on October 5. 2005 from htt://www.med pharm.co. 2a/safp/2000/oct/mellitus

[5] Iwu MM (1983): The hypoglycaemic property of Brideliaferruginea. Fitoterapia (Italy). 54(6): 243-248.

[6] Lernmark, A. Hagglof. D \& Freedman. W. (1981). A prospective analysis of antibodies reacting with pancreatic islet cells in Insulin dependent diabetic children. Diabetologia. 20.471- 474.

[7] Nimenibo-Uadia, R. (2003). Effect of Vernonia amygdalina in alloxan-induced diabetes albino rats. Journal of Medical Laboratory Science. 12(1) 25-31.

[8] Wolf E. Spencer K.M. Cudworth A.G. (1983). The genetic susceptibility to type I (insulin-dependent) diabetes: analysis of the HLA-DR association Diabetologia, 24, 224-230

[9] Uhegbu, F.O \& Ogbuehi, J. (2004). Effect of aqueous extract (cruele) of leaves of veronnia amygdaline. Del on blood glucose serum albumin and cholesterol level in diabetic albino rats. Global Journal of pure and Applied Science, 10, 189 - 194. 
Hypoglycaemic Activity and Biochemical Effects of Vernonia amygdalina with Diabenese in Normal and Diabetic Rats

[10] Winkelman M (1989). Ethnobotanical treatments of diabetes in Baja California Norte. Medical Anthropology. 11(3):255-68.

[11] World Health Organization.(1985). World health organization study group technical report on diabetes mellitus. Geneva. World Health Organization.

Citation: Jones, B.B et al., "Hypoglycaemic Activity and Biochemical Effects of Vernonia amygdalina with Diabenese in Normal and Diabetic Rats", International Journal of Clinical Chemistry and Laboratory Medicine (IJCCLM), vol. 4, no. 3, pp. 1-5, 2018. http://dx.doi.org/10.20431/2455-7153.0403001

Copyright: (c) 2018 Authors. This is an open-access article distributed under the terms of the Creative Commons Attribution License, which permits unrestricted use, distribution, and reproduction in any medium, provided the original author and source are credited. 